\title{
Design, Synthesis and Biological Evaluation of Some 5-Arylthieno[2,3-d]- pyrimidines as Potential Anti-cancer Agents
}

\author{
Afaf Kamal El-Ansary, Aliaa Mohammed Kamal,* and Mokhtar Abd-Hafiz Al-Ghorafi \\ Pharmaceutical Organic Chemistry Department, Faculty of Pharmacy, Cairo University; Cairo 11561, Egypt. \\ Received March 25, 2016; accepted May 1, 2016
}

\begin{abstract}
Structure-based design, synthesis and biological evaluation of new small molecules anti-cancer agents were described. On continuation of applying scaffold hopping theory, a series of 5-arylthieno[2,3-d]pyrimidines based on the structural features of lapatinib was designed, synthesized and characterized using IR, ${ }^{1} \mathrm{H}-\mathrm{NMR},{ }^{13} \mathrm{C}-\mathrm{NMR}$, mass and microanalyses. Biological evaluation of the cytotoxic activity against MCF-7 cell line and the inhibition of the enzymatic activity of epidermal growth factor tyrosine kinase were carried out in vitro for the target compounds. Substituting the 4-anilino-5-arylthieno[2,3- $d$ ]pyrimidines with different pharmacophoric groups at ortho, meta and/or para positions led to discovery of two potent lead compounds $3 b$ and $f$ with excellent cytotoxic activity and enzymatic inhibition activity.
\end{abstract}

Key words anti-tumor agent; nucleophilic substitution; Scaffold hopping theory; sulfonamide; thieno[2,3d]pyrimidine

Cancer is a leading cause of death worldwide, responsible for 8.2 million death in 2012. The design of new compounds prototypes has been a good strategy for discovery of new drugs. ${ }^{1,2)}$ Small molecule kinase inhibitors-4-anilinoquinazoline derivatives - have been successfully introduced to the drug market as selective antitumor agents with low side effects. $^{3-8)}$ Many small molecules e.g., gefitinib and erlotinib have been approved by the U.S. Food and Drug Administration (FDA) for treatment of certain cancers over-expressing epidermal growth factor receptor (EGFR) and various approaches were adopted to enhance the potency and selectivity of these inhibitors. These efforts led to discovery of lapatinib, a potent inhibitor of EGFR that approved by the FDA for treatment of breast cancer. ${ }^{9}$ Kinase inhibitors that compete with the ATP can be classified into two major groups. Type 1 kinase inhibitors: such as gefitinib and erlotinib which target and induce the active conformation of kinase enzymes via mimicking the binding mode of the ATP molecule. The molecular design strategies resulted in type 2 kinase inhibitors, such as lapatinib I (Fig. 1) which possesses extra structural features that enable it to bind to the inactive form of the kinases and subsequently lapatinib turned out to be more selective inhibitor than the corresponding type $1 .^{10,11)}$

Lapatinib I shows its cytotoxic activity via a unique mechanism of action and exhibits reversible, non-covalent inhibition of EGFR, but it has a very slow off-rate compared with other reversible 4-anilinoquinazoline compounds. ${ }^{7)}$ Lapatinib I binds into the ATP-binding cleft where the quinazoline ring is participating in hydrogen bond with the hinge region between the $\mathrm{NH}_{2}$ and $\mathrm{COOH}$ terminal lobes of the kinase, whereas the quinazoline ring of other inhibitors participated in hydrogen bond with EGFR differently. The binding mode of lapatinib to EGFR tyrosine kinase (TK) revealed that N1 of the quinazoline participated in hydrogen bond with the Met769 NH while the N3 interacted with the side chain of Thr766 through a water bridge. The $\mathrm{C} 2$ and the $\mathrm{C} 8$ of the quinazoline ring were positioned close to the backbone carbonyls of Gln767 and Met769, respectively. The acidic hydrogen attached to
$\mathrm{C} 2$ is hypothesized to form a unique $\mathrm{CH}-\mathrm{O}$ type of hydrogen bond with the carbonyl of Gln767. ${ }^{12)}$ The side chain of Thr766 in lapatinib-EGFR complex points away from the quinazoline and participated in hydrogen bond with the backbone carbonyl of $\operatorname{Arg} 752 .{ }^{13)}$

The 4-anilino group plays an important role in the binding and selectivity of these inhibitors. Examining the crystal structure of lapatinib-EGFR complex confirmed that large anilino substituents also entered the kinase specificity pocket.7) The large anilino substituents induced dramatic conformational changes in the ATP-binding site, the position of the C-helix and the hydrogen binding pattern with quinazoline ring. ${ }^{7,12,14)}$ Molecular modeling studies have given insights into structural features that enhanced inhibitory activity and provided theoretical models to predict activities of this class of compounds depending on the docking orientation of the ligands in the active site. ${ }^{15-17)}$

Thienopyrimidines in general have become an interesting structural element in development of pharmaceutical compounds especially anticancer agents via various mechanisms e.g., thymidylate synthase inhibitors, ${ }^{18,19)}$ Cyclin-dependent kinase inhibitors (CDKI), ${ }^{20,21)}$ Gonadotropin releasing hormone $(\mathrm{GnRH})$ receptor antagonists, $\left.{ }^{22}\right)$ tyrosine kinase inhibitors (TKIs) $^{23-27)}$ and as FGFR1 inhibitors. ${ }^{28)}$

In our previous work, ${ }^{29)}$ we replaced the benzene ring of

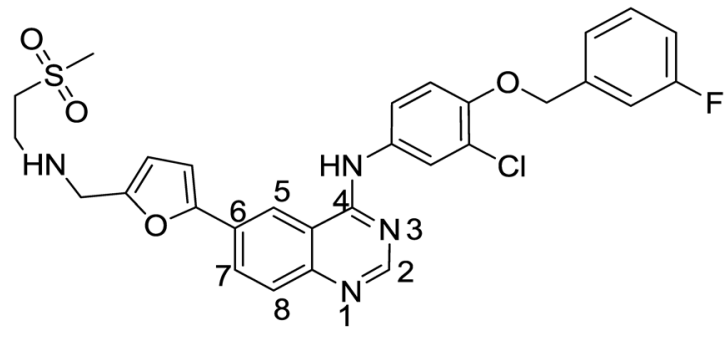

(I)

Fig. 1. Structure of Labitinib I 
the 4-anilinoquinazoline core with thiophene ring to result in 4-anilinothieno[2,3- $d$ ]pyrimidine core. Moreover, different spacers between thieno[2,3- $d]$ pyrimidine core and 4-anilino group were introduced. Also, total replacement of the aniline moiety with substituted heterocyclic rings was carried out. In the present work, we continued the strategy of the previous work in modifying the structure of the core 4-anilinoquinazoline by using 4-anilinothieno[2,3- $d$ ]pyrimidine core as well as substituting the 4-anilino moiety with small, medium and large pharmacophores e.g., benzyloxy moiety ( $\mathbf{2} \mathbf{a}$ and $\mathbf{b})$, sulfonamides (3a-j) and other small groups (4a-q) (Fig. 2).

Accordingly, the strategy of this work was the usage of the potent inhibitors' common features to design a series of potential anti-breast cancer thieno[2,3- $d]$ pyrimidine derivatives. The synthesis of the target thieno[2,3- $d]$ pyrimidine derivatives was represented in Chart 1.

\section{Results and Discussion}

Designing the Target Compounds For continuation of our previous work in designing a series of potential anti-breast cancer thieno[2,3- $d$ ]pyrimidine derivatives by using the potent inhibitors' common features ${ }^{29)}$; this work was directed to-

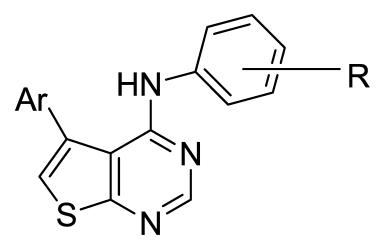

Fig. 2. General Formula of the Target Compounds $\mathbf{2 a}$ and $\mathbf{b}, \mathbf{3 a}-\mathbf{j}$ and $4 \mathbf{a}-\mathbf{q}$

Ar=4-chlorophenyl, 4-nitrophenyl, R=benzyloxy (2a and $\mathbf{b}$ ), different sulfonamides $(\mathbf{3 a}-\mathbf{j})$ and small groups $(\mathbf{4} \mathbf{a}-\mathbf{q})$. wards studying the effect of substituting the 4-anilino moiety of the 4-anilinothieno[2,3- $d]$ pyrimidine core with small, medium or large groups (benzyloxyphenyl, benzenesulfonamido, methyl, carboxyl, nitro, or halide groups) on the cytotoxic activity of the newly synthesized compounds. Introduction of bulky groups such as benzyloxy and sulfonamide moieties at para position of the aniline ring to fill a pocket in the ATP binding region as lapatinib does, was one of the possibilities, so that the bulky group could be oriented deep into the back of the ATP binding site and makes predominantly hydrophobic interaction with the protein mimicking the 3'-chloro-4[(3-fluorobenzyl)oxy]aniline group of lapatinib I. Also substitution of the anilino moiety with small groups at ortho, meta and/or para positions e.g., $\mathbf{4 a}-\mathbf{q}$ took place to evaluate the effect of both the position and the size of the substituting group on the biological activity of the target compounds. To justify the suggested compounds as good cytotoxic agents, the binding model of EGFR with some thieno[2,3- $d$ ]pyrimidine derivatives $\mathbf{2} \mathbf{a}$ and $\mathbf{b}, \mathbf{3} \mathbf{a}-\mathbf{j}$ and $\mathbf{4 a}-\mathbf{q}$ was generated (Fig. 3).

The binding model suggested that, N1 of the thieno[2,3d]pyrimidine interacted with the main chain $\mathrm{NH}$ group of Met793 in the hinge region and N3 interacted with the side chain $\mathrm{OH}$ group of Thr854 through a water mediated hydrogen bonding. The substituents at the para position of the aniline moiety extended toward the back hydrophobic pocket. Thus, the compounds were designed to possess both nitrogen atoms for binding and a lipophilic group $\left(\mathrm{R}^{1}\right)$ at the para position of the aniline moiety, via an appropriate linker $(X$, $Y$ ) (Fig. 3). Secondary amino group at $\mathrm{C} 4$ of thieno[2,3-d]pyrimidine derivatives $\mathbf{2 a}$ and $\mathbf{b}, \mathbf{3 a}-\mathbf{j}$ and $\mathbf{4 a}-\mathbf{q}$ was acting as conformational lock and extending substituted aniline portion into the hydrophobic pocket of EGFR-TK, making predominantly hydrophobic interactions with the protein. Generally,

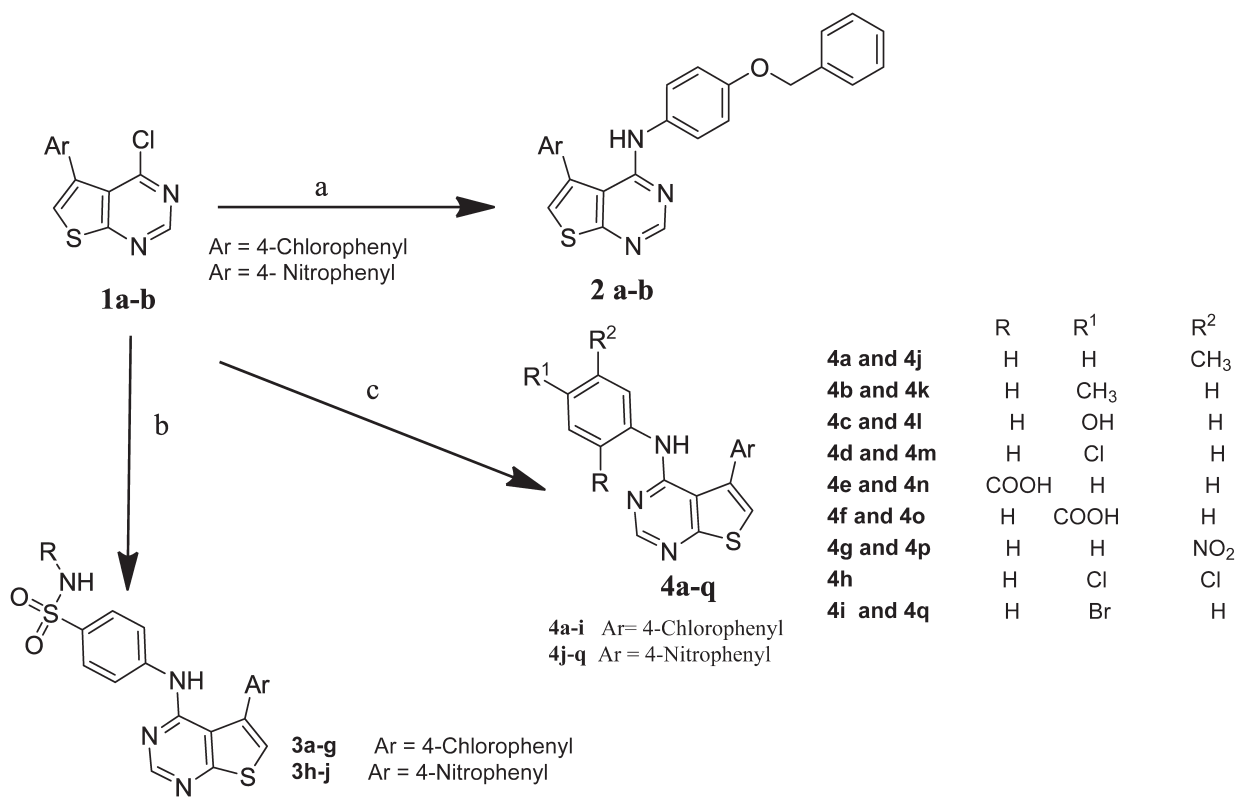

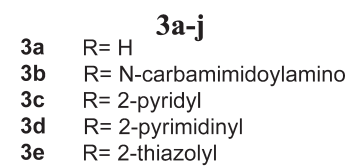

3f $\mathrm{R}=4,5$-dimethyl-3-isoxazolyl

3g $\mathrm{R}=4,6$-dimethyl-2-pyrimidinyl

3h $\mathrm{R}=\mathrm{H}$

3i $\mathrm{R}=\mathrm{N}$-carbamimidoylamino

3j $\mathrm{R}=4,6$-dimethyl-2-pyrimidinyl 
the thieno[2,3- $d]$ pyrimidine core of the suggested compounds was sandwiched between the side chains of Ala743 and Leu844, respectively, bound to the adenine binding pocket and mimicked the quinazoline ring of lapatinib I. Upon docking the target compounds into ATP of the EGFR, they were bound to the ATP catalytic domain with two or more hydrogen bonds. One was formed between N1 of the thienopyrimidine core and main chain $\mathrm{NH}$ of Met793, another was formed between N3 and side chain $\mathrm{OH}$ of Thr854 through a water mediated hydrogen bond. The benzyloxyaniline of compound $\mathbf{2} \mathbf{b}$ for example mimicked the 3-chloro-4-[(3-fluorobenzyl)oxy]aniline moiety of lapatinib I. The saved pose (Fig. 4) for the ligand-enzyme complex of compound $\mathbf{3 b}$ revealed that several molecular interactions were considered to be responsible for the observed affinity.

Moreover, Fig. 4 showed perfect overlay of lapatinib and compounds $\mathbf{2} \mathbf{b}$ and $\mathbf{3 b}$ as they both connected to the same amino acids residues with different hydrogen bond lengths (Table 1).

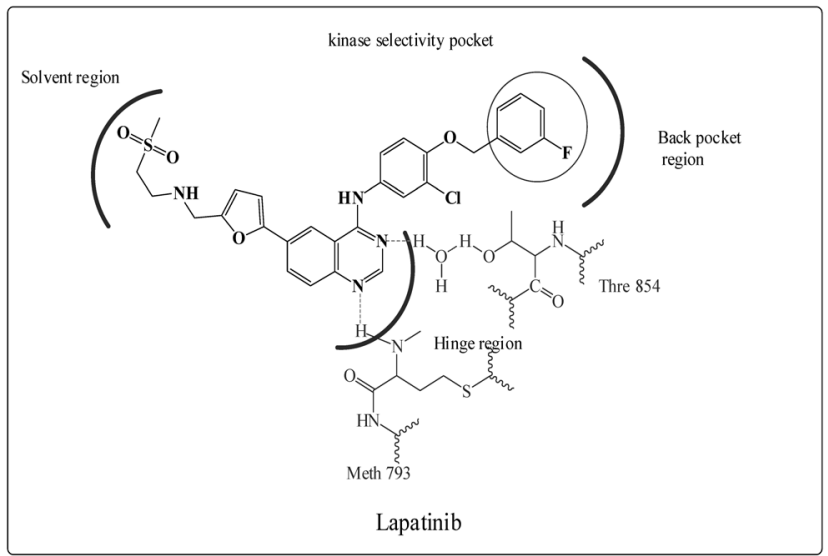

The sulfonamide moieties of compounds $\mathbf{3 a}-\mathbf{j}$ were deeply oriented in the hydrophobic pocket and made a predominant hydrophobic interaction with the adjacent lipophilic pocket lined by Met766, Leu777, Thr790, and Phe856. The additional binding energy provided by the binding of the substituted sulfonamides of compounds $\mathbf{3 a}-\mathbf{j}$ in this deep pocket may be the reason for the high binding affinity of these compounds. It was also found out that both the $p$-chlorophenyl and the $p$-nitrophenyl at $\mathrm{C} 5$ of the thieno[2,3- $d]$ pyrimidine were directed toward the solvent interface, we envisioned that aromatic ring at this position, could be utilized to further improve the cellular activity and pharmacokinetic properties of the synthesized compounds.

With the guidance of the above findings, a series of thienopyrimidine derivatives were designed, docked into EGFR-TK, synthesized and evaluated for their anti-breast cancer activity and the EGFR-TK enzymatic inhibition activity. The suggested compounds showed good binding to the receptor, good superposition and good docking scores. Their good fitting to

Fig. 3. Binding Model of Some Thieno[2,3-d]pyrimidine Scaffold to EGFR Kinase Receptor

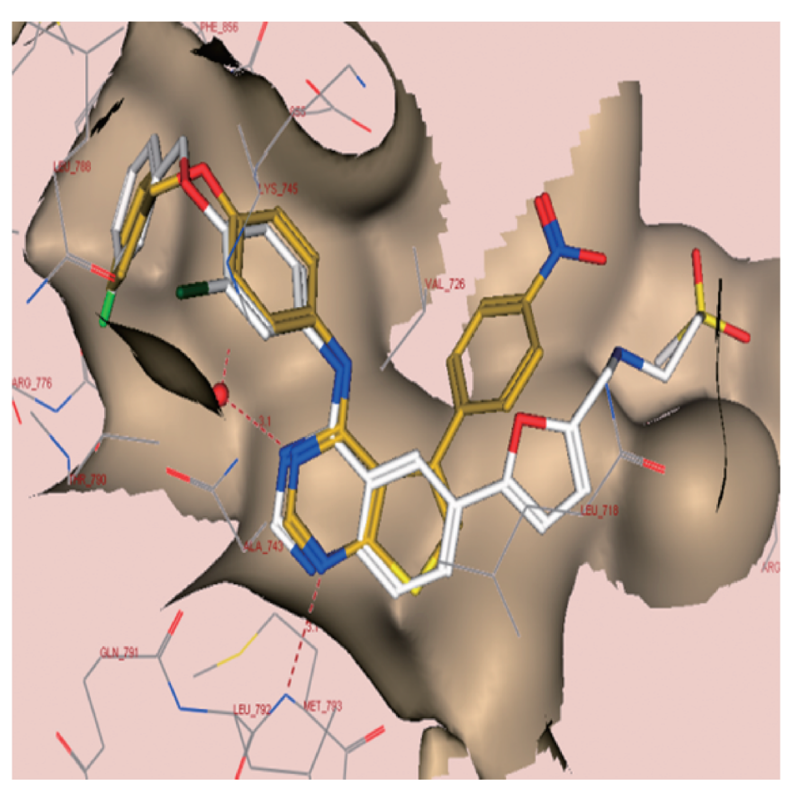

(a)

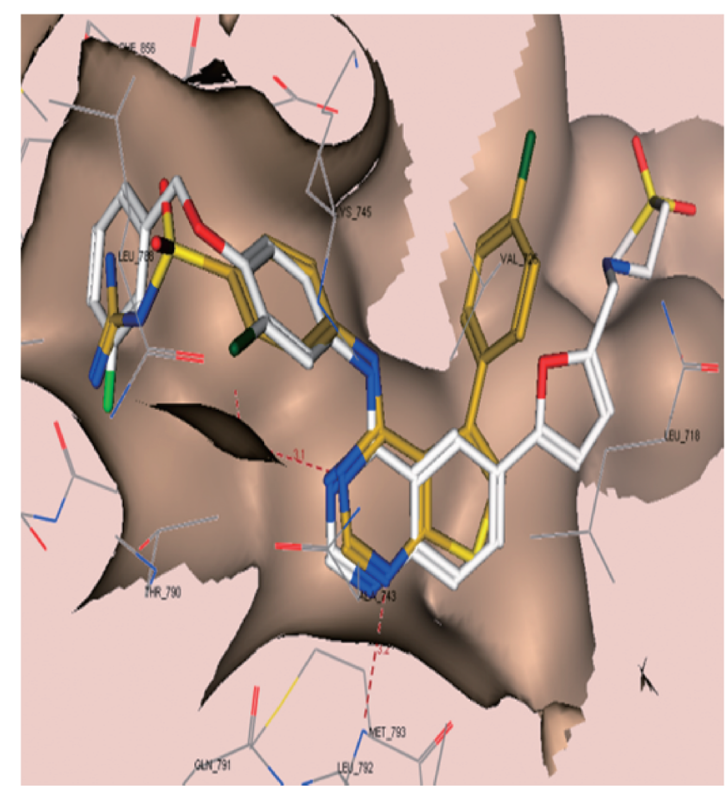

(b)

Fig. 4. (a) The Superposition of Lapatinib (White) and Compound 2b (Dark Yellow) Docked in the ATP Binding Site of EGFR PTK; (b) The Superposition of Lapatinib (White) and Compound 3b (Dark Yellow) Docked in the ATP Binding Site of EGFR PTK 
the active site pocket and good interactions with the amino acid residues (Table 1) suggested that they might show good enzymatic inhibition activity.

Synthesis of the Target Compounds Synthesis of compounds 1a and $\mathbf{b}$ was achieved via chlorination of thieno[2,3d]pyrimidin-2-ones according to a reported method. ${ }^{29)} \mathrm{Nu}$ cleophilic substitution of the 4-chloro group of compounds 1a and b with 4-benzyloxyphenylamine, 4-aminobenzenesulfon- amides or suitable aromatic amines afforded compounds $\mathbf{2 a}$ and $\mathbf{b}, \mathbf{3 a}-\mathbf{j}$ (Table 2) and $\mathbf{4 a}-\mathbf{q}$ sequentially (Chart 1).

Confirmatory evidences for structure of all the newly synthesized compounds $(\mathbf{2} \mathbf{a}, \mathbf{b}, \mathbf{3} \mathbf{a}-\mathbf{j}$ and $\mathbf{4 a}-\mathbf{q})$ were provided by elemental analysis, IR, ${ }^{1} \mathrm{H}-\mathrm{NMR},{ }^{13} \mathrm{C}-\mathrm{NMR}$ and mass spectroscopy.

Correlation between Cytotoxic Activity and Docking Results A series of thieno[2,3- $d]$ pyrimidine derivatives based

Table 1. Docking Data of the Target Compounds and Lapatinib into EGFR-TK Enzyme

\begin{tabular}{|c|c|c|c|}
\hline Compound number & Number of H-bonds & Amino acid residues forming H-bonds (H-bond length in $\AA$ ) & $\begin{array}{c}\text { Binding energy } \\
\text { score }^{b)}\end{array}$ \\
\hline Lapatinib $^{a}$ & 2 & Met793 (3.1), Thr854 (2.79), & -35.2 \\
\hline 2a & 3 & Met793 (3.2), Thr854 (3.1), $\pi$-cation (Lys745) & -34.0 \\
\hline $2 \mathbf{b}$ & 2 & Met793 (3.1), Thr854 (3.1) & -33.0 \\
\hline 3a & 2 & Met793 (3.2), Thr854 (2.9) & -32.0 \\
\hline $3 \mathbf{b}$ & 2 & Met793 (3.2), Thr854 (2.9) & -36.0 \\
\hline $3 \mathrm{c}$ & 4 & Met793 (3.2), Thr854 (2.0), Thr854 (2.0), $\pi$-cation (Lys745) & -25.0 \\
\hline 3d & 3 & Met793 (3.1), Thr854 (2.0), $\pi$-cation (Lys745) & -22.0 \\
\hline $3 e$ & 3 & Met793 (3.2), Thr854 (2.0), $\pi$-cation (Lys745) & -19.0 \\
\hline 3f & 3 & Met793 (3.2), Thr854 (2.0), $\pi$-cation (Lys745) & -36.0 \\
\hline $3 g$ & 2 & Met793 (3.2), Thr854 (2.9) & -12.0 \\
\hline $3 \mathrm{~h}$ & 3 & Met793 (3.3), Thr854 (3.2), $\pi$-cation (Lys745) & -33.0 \\
\hline $3 \mathbf{i}$ & 3 & Met793 (3.3), Thr854 (3.0), Thr854 (2.5) & -31.0 \\
\hline $4 a$ & 2 & Met793 (3.3), Thr854 (2.9) & -29.0 \\
\hline $4 \mathrm{~g}$ & 3 & Met793 (3.2), Thr854 (3.0), $\pi$-cation (Lys745) & -26.4 \\
\hline $4 h$ & 2 & Met793 (3.3), Thr854 (2.9) & -32.0 \\
\hline $4 j$ & 2 & Met793 (3.1), Thr854 (2.9) & -23.0 \\
\hline $4 p$ & 3 & Met793 (3.2), Thr854 (2.9), $\pi$-cation (Lys745) & -26.0 \\
\hline
\end{tabular}

a) Lapatinib (Tykerb ${ }^{\mathrm{TM}}$ ) was used as a standard in the docking study. $b$ ) Binding energy score (kcal/mol): energy of interaction of the ligand and organic compounds in the active site.

Table 2. The Structural Formulae of Compounds $\mathbf{3 a}-\mathbf{j}$

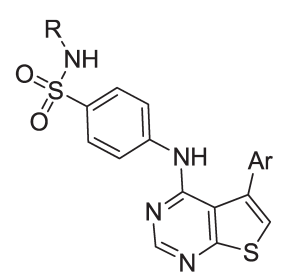

3a-j

Cpd. No.


on the structure feature of lapatinib had been synthesized and evaluated for their biological activity in vitro. Molecular docking studies helped in designing novel inhibitors and thereby helped to understand the antitumor activity against MCF-7 cell line and the enzymatic inhibition activity. Almost all of the test compounds exhibited distinguished antitumor activity against MCF-7 breast cancer cell with $\mathrm{IC}_{50}$ (concentration of compounds that is required for 50\% inhibition) ranging from 9.1 to $59.6 \mathrm{~nm}$, and using lapatinib as a reference drug with $\mathrm{IC}_{50} 11.0 \mathrm{~nm}$ (Table 3). Compound $\mathbf{3 b}$ was the most active compound with $\mathrm{IC}_{50} 9.1 \mathrm{~nm}$.

In addition most tested compounds revealed good binding mode with binding energy score ranged from -36.0 to -12.0 (lapatinib binding energy score -35.2) (Table 1). This may be attributed to that they possess the key binding features with EGFR-TK which represented in N1 and N3 of the thienopyrimidine core. Also the different pharmacophores at the para position of aniline moiety in case of compounds $\mathbf{2} \mathbf{a}$ and $\mathbf{b}$ and $\mathbf{3 a}-\mathbf{j}$ extended toward the back of ATP binding site and made a predominantly hydrophobic interaction with the protein. When the substituent at the $\mathrm{C} 4$ of aniline moiety was benzyloxy group in compounds $\mathbf{2} \mathbf{a}$ and $\mathbf{b}$, they displayed good activity ( $\mathrm{IC}_{50} 45.1$ and $31.7 \mathrm{~nm}$, respectively) (Table 3 ).

The introduction of larger groups such as heterocyclic sulfonamides at position $\mathrm{C} 4$ of the aniline moiety e.g., compounds $3 \mathbf{c}-\mathbf{g}$ showed potent activity $\left(\mathrm{IC}_{50} 28.5-46.0 \mathrm{~nm}\right)$. Upon investigating the effect of the substitution of the sulfonamide group itself, it was found that, the extra hydrophobic interaction of the five membered ring provided by 4,5 dimethyl isoxazolyl moiety in compound $\mathbf{3 f}\left(\mathrm{IC}_{50} 28.5 \mathrm{~nm}\right)$ showed better anti-breast cancer activity compared to the unsubstituted five membered ring $3 \mathbf{e}\left(\mathrm{IC}_{50} 46.0 \mathrm{~nm}\right)$. The cytotoxic activity of compounds $\mathbf{3 c}$, $\mathbf{d}$ and $\mathbf{g}$ (substituted and unsubstituted six membered heterocyclic sulfonamide derivatives) were nearly the same $\left(\mathrm{IC}_{50} 31.3,30.9,30.9 \mathrm{~nm}\right.$, respectively) and this was in contrast to the substituted and unsubstituted five membered ring derivatives $3 \mathbf{f}$ and $\mathbf{e}$. This may be attributed to the conformational structures of both five and six membered rings.

Substitutions of the anilino moiety with small electron withdrawing or electron donating groups e.g., compounds $\mathbf{4 a}-\mathbf{q}$ showed moderate activity $\left(\mathrm{IC}_{50} 45.5-59.6 \mathrm{~nm}\right.$ ) but still lower than compounds $\mathbf{2 a}$ and $\mathbf{b}$ and $\mathbf{3 a}-\mathbf{j}$ which were substituted with larger moieties at the para position of the anilino group. Compounds $\mathbf{4 a}, \mathbf{g}, \mathbf{h}, \mathbf{j}$ and $\mathbf{4 p}$ with ortho or meta substitution showed the least anti-breast cancer activity.

Nonradioactive Assay of Protein-Tyrosine Kinase (PTK)
Activity Using Anti-phosphotyrosine Antibodies The PTK assay was intended for the measurement of EGFR-TK activity. Protein tyrosine phosphorylation is a central mechanism that mediates signal transduction events involved in a wide range of cellular processes. PTKs are considered to play a critical role in signal transduction pathways. Several of the PTKs have been identified as oncogenes. Measurement of EGFRPTK activity is an essential requirement in development of EGFR-TKI in vitro. This method depends on the direct- and specific detection of only phosphorylated EGFR-TK residue using monoclonal anti-phosphotyrosine-peroxidase conjugate. The PTK activity is based on enzyme-linked immunosolvent assay (ELISA) assay. The inhibition activity of EGFR-TK was measured for the doses of the target compounds that caused $50 \%$ inhibition of MCF-7 cell line activity. Generally, compounds $\mathbf{2} \mathbf{a}$ and $\mathbf{b}$ and $\mathbf{3 a}-\mathbf{j}$ showed very good PTK inhibition activity (even better than the activity against MCF-7 cell line) compared to compounds $\mathbf{4 a}-\mathbf{q}$ and this was attributed to that they possess the key binding features with EGFR-TK specially they had bulky substitution at $\mathrm{C} 4$ position (para) of the anilino moiety. Compound $\mathbf{3 b}$ showed the highest inhibition activity of EGFR-TK enzyme with the lowest phosphorylated tyrosine kinase concentration $1.83359 \mathrm{ng} / \mathrm{mL}$ even more potent than the reference drug that showed phosphorylated tyrosine kinase concentration $2.43252 \mathrm{ng} / \mathrm{mL}$ (Table 3). Compounds 2a and $\mathbf{b}$ showed potent enzymatic inhibition activity in comparison to the reference drug with phosphorylated tyrosine kinase concentration 3.99583 and $3.12059 \mathrm{ng} / \mathrm{mL}$, respectively. Regarding compounds $\mathbf{3 a}, \mathbf{c}-\mathbf{i}$, compound $\mathbf{3 f}$ showed excellent enzymatic inhibition activity with phosphorylated tyrosine kinase concentration $2.63671 \mathrm{ng} / \mathrm{mL}$ and nearly as active as the reference drug followed by compounds $\mathbf{3 g}$, $\mathbf{d}$ and $\mathbf{c}$ with phosphorylated tyrosine kinase concentration 2.92053, 3.00051 and $3.12058 \mathrm{ng} / \mathrm{mL}$, respectively. Compound $\mathbf{3 e}$ revealed a moderate inhibition activity with phosphorylated tyrosine kinase concentration $4.00082 \mathrm{ng} / \mathrm{mL}$ while compound 3a showed the least TK inhibition activity of this group of compounds with phosphorylated tyrosine kinase concentration $4.89956 \mathrm{ng} /$ $\mathrm{mL}$. Moreover, compounds $\mathbf{4 a}, \mathbf{g}, \mathbf{h}, \mathbf{j}$ and $\mathbf{p}$ showed the least EGFR-TK inhibition activity with phosphorylated tyrosine kinase concentrations ranging from 3.99583-6.99995 ng/mL (Table 3).

\section{Conclusion}

A series of thieno[2,3- $d]$ pyrimidine derivatives based on the structure feature of lapatinib have been designed, synthe-

Table 3. Results of in Vitro Cytotoxic Activity of Tested Compounds and Lapatinib on Breast Cancer Cell Line (MCF-7) and Inhibition Activity of EGFR-TK Enzyme

\begin{tabular}{|c|c|c|c|c|c|}
\hline Compound & $\mathrm{IC}_{50}(\mathrm{nM})$ & $\begin{array}{l}\text { Tyrosine kinase conc. } \\
\qquad(\mathrm{ng} / \mathrm{mL})\end{array}$ & Compound & $\mathrm{IC}_{50}(\mathrm{~nm})$ & $\begin{array}{l}\text { Tyrosine kinase conc } \\
\qquad(\mathrm{ng} / \mathrm{mL})\end{array}$ \\
\hline Lapatinib & $11 \pm 0.1$ & 2.43252 & $3 g$ & $30.9 \pm 0.1$ & 2.92053 \\
\hline $2 a$ & $45.1 \pm 0.0$ & 3.99583 & $3 \mathrm{~h}$ & $35.1 \pm 0.0$ & 3.34586 \\
\hline $2 b$ & $31.7 \pm 2.0$ & 3.12059 & $3 \mathbf{i}$ & $35.8 \pm 2.0$ & 3.57895 \\
\hline $3 a$ & $47.5 \pm 0.0$ & 4.89956 & $4 a$ & $45.5 \pm 2.0$ & 3.99585 \\
\hline $3 b$ & $9.1 \pm 0.0$ & 1.83359 & $4 \mathrm{~g}$ & $55.6 \pm 2.0$ & 5.89966 \\
\hline $3 c$ & $31.3 \pm 0.1$ & 3.12058 & $4 h$ & $48.2 \pm 0.0$ & 4.22382 \\
\hline 3d & $30.9 \pm 0.1$ & 3.00051 & $4 j$ & $59.6 \pm 0.0$ & 6.99995 \\
\hline $3 e$ & $46.0 \pm 2.0$ & 4.00082 & $4 p$ & $45.7 \pm 2.0$ & 3.99583 \\
\hline $3 f$ & $28.5 \pm 0.1$ & 2.63671 & Control & - & 26.55291 \\
\hline
\end{tabular}


sized and evaluated for their anti-breast cancer activity as well as enzymatic inhibition activity of EGFR-TK in vitro. Molecular docking studies further helped in designing novel potent inhibitors. As a result of the docking studies, it was expected that compounds $\mathbf{2} \mathbf{a}$ and $\mathbf{b}$, the sulfonamide derivatives $\mathbf{3} \mathbf{a}-\mathbf{j}$ and compounds $\mathbf{4 a}-\mathbf{q}$ would show good cytotoxic activity due to their very close resemblance to lapatinib in the binding mode to EGFR-TK. In general the PTK assay showed better cytotoxic activity of the target compounds. Most of the tested compounds showed excellent to good biological activity in comparison with lapatinib. Broadly, compounds $\mathbf{2 a}$ and $\mathbf{b}$ and $\mathbf{3 a}-\mathbf{j}$ showed very good-excellent EGFR-TK inhibition activity due to the very close resemblance to the small molecule kinase inhibitors-4-anilinoquinazolines derivatives' structure. The variation in inhibition activity between the same derivatives owed to the conformational variations of the substituents at $\mathrm{C} 4$ position of the 4 -anilino group e.g., compounds $\mathbf{3 b}-\mathbf{g}$. Compounds $\mathbf{3 b}$ and $\mathbf{f}$ were the most biologically active compounds with $\mathrm{IC}_{50} 9.1$ and $28.5 \mathrm{~nm}$ and this was in accordance with their EGFR-TK inhibition activity with phosphorylated tyrosine kinase concentrations 1.83359 and $2.63671 \mathrm{ng} / \mathrm{mL}$, respectively due to the bulky well-fit para substituents of the 4-anilino group. Moreover, the importance of the para bulky substitution of the 4-anilino group was confirmed when compounds $\mathbf{4 a}, \mathbf{g}, \mathbf{h}, \mathbf{j}$ and $\mathbf{p}$ that have small substitutions showed the least anti-breast cancer activity as well as the EGFR-TK inhibitory activity.

\section{Experimental}

Chemistry Melting points ( $\mathrm{mp}$ ) were determined on Stuart apparatus and the values given are uncorrected. IR spectra were determined on Shimadzu IR $8400 \mathrm{~s}$ spectrophotometer $\left(\mathrm{KBr}, \mathrm{cm}^{-1}\right)$ at Faculty of Pharmacy, Cairo University, Egypt. ${ }^{1} \mathrm{H}-\mathrm{NMR}$ spectra were carried out using a Mercury, a Gemini 300-BB $300 \mathrm{MHz}$ and Joel (eca) $500 \mathrm{MHz}$ spectrophotometers using tetramethylsilane (TMS) as internal standard. Chemical shift values were recorded in ppm on $\delta$ scale, Microanalytical Center, Cairo University, Egypt, Main laboratory of the War Chemical, Chemical War Department, Ministry of Defense and National Research Centre. ${ }^{13} \mathrm{C}-\mathrm{NMR}$ spectra were carried out using Mercury and Gemini $300-\mathrm{BB} 75 \mathrm{MHz}$ spectrophotometers using TMS as internal standard. Chemical shift values were recorded in ppm on $\delta$ scale, Microanalytical Center, Cairo University, Egypt. Mass spectra were recorded on Hewlett Packard 5988 spectrometer, Microanalytical Center, Cairo University, Egypt. Elemental analyses were carried out at the Microanalytical Center, Faculty of Pharmacy, Al Azhar University, Egypt. Progress of the reactions was monitored using TLC sheets precoated with UV fluorescent silica gel Merck 60F 254. The solvent system was benzene, chloroform and methanol with different ratios and spots were visualized using UV lamp. The docking was performed using Molecular Operating Environment (MOE 2008.10). Evaluation of the cytotoxic activity was performed at the Egyptian National Cancer Institute. Enzyme assay testing was performed at VACSERA-Egypt using SIGMA Protein Tyrosine Kinase Assay Kit (specific for EGFR-TK) and ROBONIK P2000 spectrophotometer wl $450 \mathrm{~nm}$ reader. Compounds $\mathbf{1 a}$ and $\mathbf{b}$ were synthesized according to reported method. ${ }^{29)}$

5-(4-Aryl)- $N$-[4-(benzyloxy)phenyl]thieno[2,3- $d]$ pyrimidin-4-amine (2a and b) A well-stirred mixture of either thieno[2,3- $d$ ]pyrimidine 1a or b (1 mmol) and 4-benzyloxyphenylamine $(1.2 \mathrm{mmol})$ in isopropanol (for compound 1a) or in isopropanol/2-3 drops of conc. $\mathrm{HCl}$ (for compound $\mathbf{1 b}$ ) $(20 \mathrm{~mL})$ was heated under reflux for $16-18 \mathrm{~h}$. The product was either filtered, dried and crystallized from ethanol (compound 2a) or the reaction mixture was left at ambient temperature overnight then the solid formed was triturated with sodium carbonate solution $(1 \%, 0.5 \mathrm{~mL})$, stirred, filtered, and crystallized from ethanol (compound $\mathbf{2 b}$ ).

(4-Benzyloxyphenyl)-[5-(4-chlorophenyl)thieno[2,3-d]pyrimidin-4-yl]amine (2a)

Yield, 75\%. mp $144-146^{\circ} \mathrm{C}$. IR $(\mathrm{KBr}) \mathrm{cm}^{-1}$ : 3402, 3059, 3028, 1604, 2924. ${ }^{1} \mathrm{H}-\mathrm{NMR}$ (DMSO-d $\left.{ }_{6}\right) \delta: 5.08(2 \mathrm{H}, \mathrm{s}), 6.95$ $(2 \mathrm{H}, \mathrm{d}, J=9.3 \mathrm{~Hz}), 7.29(2 \mathrm{H}, \mathrm{d}, J=8.7 \mathrm{~Hz}), 7.31-7.42(9 \mathrm{H}, \mathrm{m})$, $7.67(1 \mathrm{H}, \mathrm{s}), 7.68(1 \mathrm{H}, \mathrm{s}), 8.49(1 \mathrm{H}, \mathrm{s})$. GC-MS (electrospray ionization (ESI)) $m / z$ : $445\left(\mathrm{M}+2 \neg^{+\cdot}\right), 443\left(\mathrm{M} \neg^{+}\right), 352(\mathrm{M}-$ $\left.\mathrm{C}_{6} \mathrm{H}_{5}-\mathrm{CH}_{2} \neg^{+}\right)$. Anal. Calcd for $\mathrm{C}_{25} \mathrm{H}_{18} \mathrm{ClN}_{3} \mathrm{OS}$ : C, 67.64; H, 4.09; N, 9.47. Found: C, 67.56; H, 4.08; N, 9.78.

(4-Benzyloxy-phenyl)-[5-(4-nitrophenyl)thieno[2,3-d]pyrimidin-4-yl]amine (2b)

Yield, 68\%. mp 192-194 ${ }^{\circ} \mathrm{C} .{ }^{1} \mathrm{H}-\mathrm{NMR}\left(\mathrm{DMSO}-d_{6}\right) \delta: 5.07$ $(2 \mathrm{H}, \mathrm{s}), 6.93(2 \mathrm{H}, \mathrm{d}, J=9 \mathrm{~Hz}), 7.30-7.44(8 \mathrm{H}, \mathrm{m}), 7.67(1 \mathrm{H}$, s), $7.82(2 \mathrm{H}, \mathrm{d}, J=9.3 \mathrm{~Hz}), 8.32(2 \mathrm{H}, \mathrm{d}, J=8.7 \mathrm{~Hz}), 8.49(1 \mathrm{H}$, s). ${ }^{13} \mathrm{C}-\mathrm{NMR}$ (DMSO- $d_{6}$ ) $\delta$ : 167.7, 157.1, 152.5, 148.5, 142.6, $142.3,140.9,139.0,128.7,128.2,127.9,127.5,127.3,124.4$, 124.1, 121.8, 116.1, 114.9, 77.8. IR (KBr) cm $\mathrm{cm}^{-1}$ 3417, 3028, 3062, 3101, 1600, 2916. GC-MS (ESI) $m / z: 455\left(\mathrm{M}+1 \neg^{+\cdot}\right)$. Anal. Calcd for $\mathrm{C}_{25} \mathrm{H}_{18} \mathrm{~N}_{4} \mathrm{O}_{3} \mathrm{~S}$ : C, 66.07; H, 3.99; N, 12.33. Found: C, 66.12; H, 4.04; N, 12.45 .

5-(4-Aryl)-4-[4-(N-(substituted) sulfomyl)]anilinothieno[2,3-d]pyrimidine (3a-j) A stirred mixture of either thieno[2,3- $d]$ pyrimidine $\mathbf{1 a}$ or $\mathbf{b}(1 \mathrm{mmol})$ and the appropriate sulfonamide derivative $(1.2 \mathrm{mmol})$ in dry pyridine (for compounds $\mathbf{3 b}$ and $\mathbf{i}$ ) or isopropanol (for the rest of compounds) $(20 \mathrm{~mL})$ was heated under reflux for $18-24 \mathrm{~h}$. The reaction mixture was cooled and the formed solid was filtered, dried and crystallized from the appropriate solvent.

4-[5-(4-Chlorophenyl)thieno[2,3-d]pyrimidin-4-ylamino]benzenesulfonamide (3a)

Yield, 80\% (ethanol). mp 202-204 ${ }^{\circ} \mathrm{C} .{ }^{1} \mathrm{H}-\mathrm{NMR}$ (DMSO- $d_{6}$ ) $\delta: 7.24(2 \mathrm{H}, \mathrm{s}), 7.57-7.59(4 \mathrm{H}, \mathrm{m}), 7.72-7.78(4 \mathrm{H}, \mathrm{m}), 7.69(1 \mathrm{H}$, s), $7.79(1 \mathrm{H}, \mathrm{s}), 8.65(1 \mathrm{H}, \mathrm{s}) .{ }^{13} \mathrm{C}-\mathrm{NMR}\left(\mathrm{DMSO}-d_{6}\right) \delta: 167.5$, $157.3,149.9,142.4,134.7,133.9,129.4,129.1,128.4,128.2$, $126.5,124.5,121.9,115.6$. IR (KBr) $\mathrm{cm}^{-1}: 3402,3305,3232$, 3066, 1604, 1330. GC-MS (ESI) $m / z: 418\left(\mathrm{M}+2 \neg^{+\cdot}\right), 416$ $\left(\mathrm{M} \neg^{+\cdot}\right), 415\left(\mathrm{M}-1 \neg^{+\cdot}\right)$. Anal. Calcd for $\mathrm{C}_{18} \mathrm{H}_{13} \mathrm{ClN}_{4} \mathrm{O}_{2} \mathrm{~S}_{2}: \mathrm{C}$, 51.86; H, 3.14; N, 13.44. Found: C, 51.93; H, 3.17; N, 13.71.

$N$-Carbamimidoyl-4- $\{[5$-(4-chlorophenyl)thieno[2,3-d]pyrimidin-4-yl]amino benzenesulfonamide (3b)

Yield, 69\% (acetone). mp 208-210 ${ }^{\circ} \mathrm{C} .{ }^{1} \mathrm{H}-\mathrm{NMR}$ (DMSO- $d_{6}$ ) $\delta: 7.47-7.56(4 \mathrm{H}, \mathrm{m}), 7.49-7.51(5 \mathrm{H}, \mathrm{m}), 7.55-7.56(4 \mathrm{H}, \mathrm{m})$, $7.58(1 \mathrm{H}, \mathrm{s}), 8.34(1 \mathrm{H}, \mathrm{s})$. GC-MS (ESI) $m / z: 459\left(\mathrm{M}^{+}{ }^{+}\right)$. IR $(\mathrm{KBr}) \mathrm{cm}^{-1}:$ 3448, 3383, 3197, 3089, 1631, 1300. Anal. Calcd for $\mathrm{C}_{19} \mathrm{H}_{15} \mathrm{ClN}_{6} \mathrm{O}_{2} \mathrm{~S}_{2}$ : C, 49.72; H, 3.29; N, 18.31. Found: C, 49.84; H, 3.34; N, 18.52.

4-[5-(4-Chlorophenyl)thieno[2,3- $d$ ] pyrimidin-4-ylamino]- $N$ pyridin-2-ylbenzenesulfonamide $(\mathbf{3 c})$

Yield, 64\% (ethanol). mp $220-222^{\circ} \mathrm{C}$. ${ }^{1} \mathrm{H}-\mathrm{NMR}$ (DMSO$\left.d_{6}\right) \delta: 6.85(1 \mathrm{H}, \mathrm{t}, J=12.6,12.6 \mathrm{~Hz}), 7.13(1 \mathrm{H}, \mathrm{d}, J=8.7 \mathrm{~Hz})$, $7.53-7.60(4 \mathrm{H}, \mathrm{m}), 7.68-7.71(1 \mathrm{H}, \mathrm{t}, J=12,12 \mathrm{~Hz}), 7.73-7.78$ $(4 \mathrm{H}, \mathrm{m}), 7.81(1 \mathrm{H}, \mathrm{s}), 7.97(1 \mathrm{H}, \mathrm{s}), 8.03(1 \mathrm{H}, \mathrm{d}, J=4.5 \mathrm{~Hz}), 8.64$ 
$(1 \mathrm{H}, \mathrm{s}), 12.01(1 \mathrm{H}, \mathrm{s}) .{ }^{13} \mathrm{C}-\mathrm{NMR}$ (DMSO-d $) \delta: 167.9,161.2$, $157.3,150.0,148.8,142.6,138.2,134.5,133.7,129.6,129.2$, $128.8,128.2,126.4,124.6,121.8,115.4,113.1,108.4$. IR (KBr) $\mathrm{cm}^{-1}:$ 3390, 3047, 1597, 1354. Anal. Calcd for $\mathrm{C}_{23} \mathrm{H}_{16} \mathrm{ClN}_{5} \mathrm{O}_{2} \mathrm{~S}_{2}$ : C, 55.92; H, 3.26; N, 14.18. Found: C, 56.01; H, 3.32; N, 14.32.

4-[5-(4-Chlorophenyl)thieno[2,3-d]pyrimidin-4-ylamino]- $N$ pyrimidin-2-yl-benzenesulfonamide (3d)

Yield, 63\% (acetone). mp 310-312 ${ }^{\circ} \mathrm{C}$. ${ }^{1} \mathrm{H}-\mathrm{NMR}$ (DMSO$\left.d_{6}\right) \delta: 5.37(2 \mathrm{H}, \mathrm{brs}), 6.33-6.36(4 \mathrm{H}, \mathrm{m}), 6.42(1 \mathrm{H}, \mathrm{t}, J=9.3$, $9.3 \mathrm{~Hz}), 7.43-7.45(5 \mathrm{H}, \mathrm{m}), 8.07(2 \mathrm{H}, \mathrm{d}, J=4.8 \mathrm{~Hz}), 8.09(1 \mathrm{H}$, s). ${ }^{13} \mathrm{C}-\mathrm{NMR}\left(\mathrm{DMSO}-d_{6}\right) \delta$ : 169.4, 167.8, 157.3, 150.1, 142.6, $134.4,133.9,129.5,129.2,128.5,128.2,126.2,124.5,121.7$, 115.2, 110.7. IR (KBr) cm $\mathrm{cm}^{-1}$ :3418, 3298, 1628, 1357. Anal. Calcd for $\mathrm{C}_{22} \mathrm{H}_{15} \mathrm{ClN}_{6} \mathrm{O}_{2} \mathrm{~S}_{2}: \mathrm{C}, 53.38 ; \mathrm{H}, 3.05 ; \mathrm{N}, 16.98$. Found: C, 53.52; H, 3.02; N, 17.12 .

4-[5-(4-Chlorophenyl)thieno[2,3-d]pyrimidin-4-ylamino]- $N$ thiazol-2-yl-benzenesulfonamide (3e)

Yield, 72\% (ethanol). mp $223-225^{\circ} \mathrm{C} .{ }^{1} \mathrm{H}-\mathrm{NMR}$ (DMSO- $d_{6}$ ) $\delta: 6.81(1 \mathrm{H}, \mathrm{d}, J=4.5 \mathrm{~Hz}), 7.24(1 \mathrm{H}, \mathrm{d}, J=5.4 \mathrm{~Hz}), 7.53-7.61$ $(4 \mathrm{H}, \mathrm{m}), 7.70-7.73(4 \mathrm{H}, \mathrm{m}), 7.77(1 \mathrm{H}, \mathrm{s}), 7.98(1 \mathrm{H}, \mathrm{s}), 8.64(1 \mathrm{H}$, s), $12.68(1 \mathrm{H}, \mathrm{s}) .{ }^{13} \mathrm{C}-\mathrm{NMR}$ (DMSO- $\left.d_{6}\right) \delta: 171.5,167.8,157.1$, $149.8,142.3,138.8,134.9,133.9,129.7,129.3,128.5,126.2$, 124.2, 121.7, 115.4, 108.7. IR (KBr) $\mathrm{cm}^{-1}: 3390,3093,1598$, 1327. GC-MS (ESI) $m / z$ : $502\left(\mathrm{M}+2 \neg^{+\cdot}\right), 500\left(\mathrm{M} \neg^{+\cdot}\right), 336$ $\left(\mathrm{M}-\mathrm{C}_{3} \mathrm{H}_{3} \mathrm{~N}_{2} \mathrm{O}_{2} \mathrm{~S}_{2} \neg^{+\cdot}\right)$. Anal. Calcd for $\mathrm{C}_{21} \mathrm{H}_{14} \mathrm{ClN}_{5} \mathrm{O}_{2} \mathrm{~S}_{3}$ : C, 50.44; H, 2.82; N, 14.01. Found: C, 50.49; H, 2.78; N, 14.22.

4-[5-(4-Chlorophenyl)thieno[2,3-d]pyrimidin-4-ylamino]- $N$ (4,5-dimethylisoxazol-3-yl)benzenesulfonamide (3f)

Yield, $60 \%$ (ethanol). mp $178-180^{\circ} \mathrm{C}$. ${ }^{1} \mathrm{H}-\mathrm{NMR}$ (DMSOd $) \delta: 1.60(3 \mathrm{H}, \mathrm{s}), 2.08(3 \mathrm{H}, \mathrm{s}), 6.20(1 \mathrm{H}, \mathrm{s}), 6.57(2 \mathrm{H}, \mathrm{d}$, $J=8.7 \mathrm{~Hz}), 7.33(2 \mathrm{H}, \mathrm{d}, J=8.7 \mathrm{~Hz}), 7.36-7.53$ (4H, m), 8.06 $(1 \mathrm{H}, \mathrm{s}), 8.98(1 \mathrm{H}, \mathrm{s}), 10.49(1 \mathrm{H}, \mathrm{s}) . \mathrm{IR}(\mathrm{KBr}) \mathrm{cm}^{-1}:$ 3444, 3379, 3089, 1628, 1346. Anal. Calcd for $\mathrm{C}_{23} \mathrm{H}_{18} \mathrm{ClN}_{5} \mathrm{O}_{3} \mathrm{~S}_{2}$ : C, 53.95; H, 3.54; N, 13.68. Found: C, 54.01; H, 3.83; N, 13.40 .

4-[5-(4-Chlorophenyl)thieno[2,3-d]pyrimidin-4-ylamino]- $N$ (4,6-dimethylpyrimidin-2-yl)benzenesulfonamide (3g)

Yield, 60\% (ethanol). mp 230-232 ${ }^{\circ} \mathrm{C}$. ${ }^{1} \mathrm{H}-\mathrm{NMR}$ (DMSO$\left.d_{6}\right) \delta: 2.24(6 \mathrm{H}, \mathrm{s}), 6.76(1 \mathrm{H}, \mathrm{s}), 7.52-7.60(6 \mathrm{H}, \mathrm{m}), 7.78(1 \mathrm{H}$, s), $7.89(2 \mathrm{H}, \mathrm{d}, J=8.7 \mathrm{~Hz}), 7.92(1 \mathrm{H}, \mathrm{s}), 7.98(1 \mathrm{H}, \mathrm{s}), 8.65(1 \mathrm{H}$, s). ${ }^{13} \mathrm{C}-\mathrm{NMR}$ (DMSO- $d_{6}$ ) $\delta$ : 168.5, 167.6, 166.1, 149.9, 142.3, $134.6,133.8,129.4,129.3,128.4,128.2,126.3,124.4,121.8$, 115.4, 109.7, 21.2. IR (KBr) cm $\mathrm{cm}^{-1}$ : 3371, 3062, 1597, 1327. Anal. Calcd for $\mathrm{C}_{24} \mathrm{H}_{19} \mathrm{ClN}_{6} \mathrm{O}_{2} \mathrm{~S}_{2}$ : C, 55.11; H, 3.66; N, 16.07. Found: C, 54.77; H, 3.37; N, 15.93 .

4-[5-(4-Nitrophenyl)thieno[2,3-d]pyrimidin-4-ylamino]benzenesulfonamide (3h)

Yield, 74\% (ethanol). mp $263-265^{\circ} \mathrm{C} .{ }^{1} \mathrm{H}-\mathrm{NMR}$ (DMSO- $d_{6}$ ) $\delta: 7.24(3 \mathrm{H}, \mathrm{s}), 7.58(2 \mathrm{H}, \mathrm{d}, J=9 \mathrm{~Hz}), 7.70(2 \mathrm{H}, \mathrm{d}, J=9 \mathrm{~Hz}), 7.82$ $(2 \mathrm{H}, \mathrm{d}, J=9 \mathrm{~Hz}), 7.98(1 \mathrm{H}, \mathrm{s}), 8.30(2 \mathrm{H}, \mathrm{d}, J=8.7 \mathrm{~Hz}), 8.68(1 \mathrm{H}$, s). ${ }^{13} \mathrm{C}-\mathrm{NMR}\left(\mathrm{DMSO}-d_{6}\right) \delta$ : 167.8, 157.1, 149.8, 148.4, 142.6, $142.2,129.3,128.2,127.9,126.3,124.4,124.2,121.8,115.4$. IR (KBr) cm $\mathrm{cm}^{-1}: 3387,3302,3190,3062,1600,1348 . \mathrm{MS}$ (ESI) $m / z$ : $427\left(\mathrm{M}^{+}\right)$. Anal. Calcd for $\mathrm{C}_{18} \mathrm{H}_{13} \mathrm{~N}_{5} \mathrm{O}_{4} \mathrm{~S}_{2}: \mathrm{C}, 50.58 ; \mathrm{H}$, 3.07; N, 16.38. Found: C, 50.62; H, 3.11; N, 16.43 .

$\mathrm{N}$-Carbamimidoyl-4-\{[5-(4-nitrophenyl)thieno[2,3-d]pyrimidin-4-yl]amino\}benzenesulfonamide (3i)

Yield, 51\% (acetone). mp 240-242 ${ }^{\circ} \mathrm{C}$. ${ }^{1} \mathrm{H}-\mathrm{NMR}$ (DMSO$\left.d_{6}\right) \delta: 6.65(4 \mathrm{H}, \mathrm{brs}), 7.53(2 \mathrm{H}, \mathrm{d}, J=7.8 \mathrm{~Hz}), 7.64(2 \mathrm{H}, \mathrm{d}$, $J=8.7 \mathrm{~Hz}), 7.82(2 \mathrm{H}, \mathrm{d}, J=8.4 \mathrm{~Hz}), 7.96(1 \mathrm{H}, \mathrm{s}), 8.20(1 \mathrm{H}, \mathrm{s})$, $8.31(2 \mathrm{H}, \mathrm{d}, J=9 \mathrm{~Hz}), 8.34(1 \mathrm{H}, \mathrm{s}) .{ }^{13} \mathrm{C}-\mathrm{NMR}\left(\mathrm{DMSO}-d_{6}\right) \delta$ : $167.3,158.2,149.9,148.3,142.9,142.1,130.62,129.7,128.2$,
127.7, 126.6, 124.5, 123.9, 121.8, 115.4. IR (KBr) $\mathrm{cm}^{-1}$ : 3414, 3325, 3105, 1345. MS (ESI) $\mathrm{m} / z$ : $469\left(\mathrm{M}^{{ }^{+}}\right)$. Anal. Calcd for $\mathrm{C}_{19} \mathrm{H}_{15} \mathrm{~N}_{7} \mathrm{O}_{4} \mathrm{~S}_{2}: \mathrm{C}, 48.61 ; \mathrm{H}, 3.22 ; \mathrm{N}, 20.88$. Found: C, 48.58; H, $3.25 ; \mathrm{N}, 20.98$.

$N$-(4,6-Dimethylpyrimidin-2-yl)-4-[5-(4-nitrophenyl)thieno[2,3- $d$ ]pyrimidin-4-ylamino]benzenesulfonamide (3j)

Yield, 55\% (ethanol). mp 270-272 ${ }^{\circ} \mathrm{C} .{ }^{1} \mathrm{H}-\mathrm{NMR}$ (DMSO- $d_{6}$ ) $\delta: 2.23(6 \mathrm{H}, \mathrm{s}), 6.73(1 \mathrm{H}, \mathrm{s}), 7.58(1 \mathrm{H}, \mathrm{d}, J=8.7 \mathrm{~Hz}), 7.72(1 \mathrm{H}$, s), $7.78-7.82(3 \mathrm{H}, \mathrm{m}), 7.88(1 \mathrm{H}, \mathrm{d}, J=8.7 \mathrm{~Hz}), 7.91(1 \mathrm{H}, \mathrm{s}), 8.16$ $(1 \mathrm{H}, \mathrm{s}), 8.20-8.26(3 \mathrm{H}, \mathrm{m}), 8.67(1 \mathrm{H}, \mathrm{s}) .{ }^{13} \mathrm{C}-\mathrm{NMR}$ (DMSO- $\left.d_{6}\right)$ $\delta: 168.5,167.6,166.1,157.1,149.9,148.4,142.6,142.3,129.3$, $128.2,127.9,126.3,124.4,124.2,121.8,115.4,109.6,21.2$. IR (KBr) $\mathrm{cm}^{-1}$ : 3371, 3085, 1355. Anal. Calcd for $\mathrm{C}_{24} \mathrm{H}_{19} \mathrm{~N}_{7} \mathrm{O}_{4} \mathrm{~S}_{2}$ : C, 54.02; H, 3.59; N, 18.38. Found: C, 54.10; H, 3.63; N, 18.51.

5-(4-Aryl)- $N$-substituted Arylthieno[2,3- $d]$ pyrimidin-4amine $(\mathbf{4} \mathbf{a}-\mathbf{q})$ A well-stirred mixture of either thieno[2,3$d$ ]pyrimidine 1a or b $(1 \mathrm{mmol})$ and appropriate aniline derivatives $(1.2 \mathrm{mmol})$ in either isopropanol for compound $\mathbf{1 a}$ or isopropanol/2-3 drops conc. $\mathrm{HCl}$ for compound $\mathbf{1 b}(20 \mathrm{~mL})$ was heated under reflux for $12-16 \mathrm{~h}$. The product was either cooled and the separated solid was filtered, dried and crystallized from the appropriate solvent for compounds $\mathbf{4 a}-\mathbf{i}$ or the reaction mixture was left at ambient temperature overnight, then the formed solid was triturated in sodium carbonate solution $(1 \%, 0.5 \mathrm{~mL})$, stirred, filtered, and crystallized from the appropriate solvent for compounds $\mathbf{4 j}-\mathbf{q}$.

[5-(4-Chlorophenyl)thieno[2,3-d]pyrimidin-4-yl]m-tolylamine (4a)

Yield, $73 \%$ (acetone). mp $125-127^{\circ} \mathrm{C} .{ }^{1} \mathrm{H}-\mathrm{NMR}$ (DMSO- $d_{6}$ ) $\delta: 2.26(3 \mathrm{H}, \mathrm{s}), 6.86(1 \mathrm{H}, \mathrm{d}, J=6.3 \mathrm{~Hz}), 7.11-7.18(2 \mathrm{H}, \mathrm{m}), 7.21$ $(1 \mathrm{H}, \mathrm{s}), 7.30(1 \mathrm{H}, \mathrm{s}), 719-7.59(4 \mathrm{H}, \mathrm{m}), 7.66(1 \mathrm{H}, \mathrm{s}), 8.56(1 \mathrm{H}$, s). ${ }^{13} \mathrm{C}-\mathrm{NMR}\left(\mathrm{DMSO}-d_{6}\right) \delta: 167.6,157.1,146.4,142.3,138.6$, $134.5,133.8,129.4,129.2,128.4,128.2,124.4,121.8,119.4$, 115.8, 112.1, 20.9. IR (KBr) cm $\mathrm{cm}^{-1}: 3410,3082,1610$. GC-MS (ESI) $m / z: 353\left(\mathrm{M}+2 \neg^{+\cdot}\right), 351\left(\mathrm{M} \neg^{+\cdot}, 46\right), 350\left(\mathrm{M}-1 \neg^{+\cdot}\right)$. Anal. Calcd for $\mathrm{C}_{19} \mathrm{H}_{14} \mathrm{ClN}_{3} \mathrm{~S}$ : C, 64.86; H, 4.01; N, 11.94 . Found: C, 65.15; H, 4.07; N, 12.22.

[5-(4-Chlorophenyl)thieno[2,3-d]pyrimidin-4-yl]p-tolylamine (4b)

Yield, 75\% (acetone). mp $188-190{ }^{\circ} \mathrm{C} .{ }^{1} \mathrm{H}-\mathrm{NMR}$ (DMSO- $d_{6}$ ) $\delta: 2.31(3 \mathrm{H}, \mathrm{s}), 7.10(2 \mathrm{H}, \mathrm{d}, J=8.7 \mathrm{~Hz}), 7.27(2 \mathrm{H}, \mathrm{d}, J=8.7 \mathrm{~Hz})$, $7.38(1 \mathrm{H}, \mathrm{s}), 7.56-7.62(4 \mathrm{H}, \mathrm{m}), 7.70(1 \mathrm{H}, \mathrm{s}), 8.54(1 \mathrm{H}, \mathrm{s})$. ${ }^{13} \mathrm{C}-\mathrm{NMR}$ (DMSO- $d_{6}$ ) $\delta: 167.6,157.1,143.4,142.3,134.6$, 133.8, 130.0, 129.4, 128.4, 128.2, 127.6, 124.4, 115.0, 20.8. IR $(\mathrm{KBr}) \mathrm{cm}^{-1}:$ 3414, 3082, 3051, 1608, 2925. Anal. Calcd for $\mathrm{C}_{19} \mathrm{H}_{14} \mathrm{ClN}_{3} \mathrm{~S}$ : C, 64.86; H, 4.01; N, 11.94. Found: C, 64.97; H, 4.12; N, 12.21 .

4-[5-(4-Chlorophenyl)thieno[2,3-d]pyrimidin-4-ylamino]phenol (4c)

Yield, 70\% (ethanol). mp 300-302 ${ }^{\circ} \mathrm{C} .{ }^{1} \mathrm{H}-\mathrm{NMR}$ (DMSO$\left.d_{6}\right) \delta: 6.69(2 \mathrm{H}, \mathrm{d}, J=8.7 \mathrm{~Hz}), 7.14(2 \mathrm{H}, \mathrm{d}, J=9 \mathrm{~Hz}), 7.18(1 \mathrm{H}$, s), 7.46-7.51 (4H, m), $7.64(1 \mathrm{H}, \mathrm{s}), 8.45(1 \mathrm{H}, \mathrm{s}), 9.30(1 \mathrm{H}, \mathrm{s})$. ${ }^{13} \mathrm{C}-\mathrm{NMR}$ (DMSO- $d_{6}$ ) $\delta$ : 167.6, 157.1, 147.4, 142.3, 139.3, 134.6, 133.8, 129.4, 128.4, 128.2, 124.4, 121.8, 116.4. IR (KBr) $\mathrm{cm}^{-1}$ : 3444, 3402, 3097, 3026, 1608, 2920. Anal. Calcd for $\mathrm{C}_{18} \mathrm{H}_{12} \mathrm{ClN}_{3} \mathrm{OS}$ : C, 61.10; H, 3.42; N, 11.88. Found: C, 61.06; H, $3.49 ; \mathrm{N}, 12.02$.

(4-Chlorophenyl)[5-(4-chlorophenyl)thieno[2,3-d]pyrimidin-4-yl]amine (4d)

Yield, 82\% (isopropanol). mp $162-164^{\circ} \mathrm{C} .{ }^{1} \mathrm{H}-\mathrm{NMR}$ (DMSO$\left.d_{6}\right) \delta: 7.34(2 \mathrm{H}, \mathrm{d}, J=9 \mathrm{~Hz}), 7.37(2 \mathrm{H}, \mathrm{d}, J=9 \mathrm{~Hz}), 7.45-7.63$ 
$(4 \mathrm{H}, \mathrm{m}), 7.66(1 \mathrm{H}, \mathrm{s}), 7.74(1 \mathrm{H}, \mathrm{s}), 8.58(1 \mathrm{H}, \mathrm{s}) . \mathrm{IR}(\mathrm{KBr}) \mathrm{cm}^{-1}$ : 3406, 3066, 1604. GC-MS (ESI) $\mathrm{m} / \mathrm{z}: 374\left(\mathrm{M}+2 \neg^{+\cdot}\right), 372$ $\left(\mathrm{M} \neg^{+\cdot}\right), 370\left(\mathrm{M}-2 \neg^{+}\right)$. Anal. Calcd for $\mathrm{C}_{18} \mathrm{H}_{11} \mathrm{Cl}_{2} \mathrm{~N}_{3} \mathrm{~S}: \mathrm{C}$, 58.07; H, 2.98; N, 11.29. Found: C, 58.14; H, 3.02; N, 11.38 .

2-[5-(4-Chlorophenyl)thieno[2,3-d]pyrimidin-4-ylamino]benzoic Acid (4e)

Yield, 69\% (acetone). mp 262-264 ${ }^{\circ} \mathrm{C} .{ }^{1} \mathrm{H}-\mathrm{NMR}$ (DMSO$\left.d_{6}\right) \delta: 7.42-7.46(4 \mathrm{H}, \mathrm{m}), 7.53(1 \mathrm{H}, \mathrm{s}), 7.54-7.57(4 \mathrm{H}, \mathrm{m}), 8.14$ $(1 \mathrm{H}, \mathrm{s}), 8.15(1 \mathrm{H}, \mathrm{s}), 12.51(1 \mathrm{H}, \mathrm{s}) . \mathrm{IR}(\mathrm{KBr}) \mathrm{cm}^{-1}: 3402,3360$, 3067, 1685, 1581. GC-MS (ESI) $m / z: 383\left(\mathrm{M}+2 \neg^{+\cdot}\right), 382$ $\left(\mathrm{M}+1 \neg^{+\cdot}\right)$, 381 $\left(\mathrm{M}^{+}{ }^{+\cdot}\right)$. Anal. Calcd for $\mathrm{C}_{19} \mathrm{H}_{12} \mathrm{ClN}_{3} \mathrm{O}_{2} \mathrm{~S}: \mathrm{C}$, 59.76; H, 3.17; N, 11.00. Found: C, 59.73; H, 3.22; N, 11.12 .

4-[5-(4-Chlorophenyl)thieno[2,3-d]pyrimidin-4-ylamino]benzoic Acid (4f)

Yield, 72\% (acetic acid). mp $303-305^{\circ} \mathrm{C} .{ }^{1} \mathrm{H}-\mathrm{NMR}$ (DMSO$\left.d_{6}\right) \delta: 7.50(2 \mathrm{H}, \mathrm{d}, J=8.4 \mathrm{~Hz}), 7.58-7.66(4 \mathrm{H}, \mathrm{m}), 7.74(1 \mathrm{H}, \mathrm{s})$, $7.86(2 \mathrm{H}, \mathrm{d}, J=8.4 \mathrm{~Hz}), 7.89(1 \mathrm{H}, \mathrm{s}), 8.66(1 \mathrm{H}, \mathrm{s}), 12.50(1 \mathrm{H}$, s). ${ }^{13} \mathrm{C}-\mathrm{NMR}$ (DMSO- $d_{6}$ ) $\delta$ : 172.0, 167.6, 157.1, 151.8, 142.3, $134.6,133.7,130.9,129.3,128.5,128.2,124.4,121.8,120.6$, 115.0. IR (KBr) cm $\mathrm{cm}^{-1}: 3483,3402,3074,1689,1605 . \mathrm{MS}$ (ESI) $m / z: 383\left(\mathrm{M}+2 \neg^{+}\right), 382\left(\mathrm{M}+1 \neg^{+\cdot}\right), 337\left(\mathrm{M}-\mathrm{COOH} \neg^{+\cdot}\right)$. Anal. Calcd for $\mathrm{C}_{19} \mathrm{H}_{12} \mathrm{ClN}_{3} \mathrm{O}_{2} \mathrm{~S}$ : C, 59.76; H, 3.17; N, 11.00 . Found: C, 59.92; H, 3.23; N, 11.31.

[5-(4-Chlorophenyl)thieno[2,3-d]pyrimidin-4-yl]-(3nitrophenyl)amine (4g)

Yield, 70\% (acetone). mp $160-162{ }^{\circ} \mathrm{C}$. ${ }^{1} \mathrm{H}-\mathrm{NMR}$ (DMSO$\left.d_{6}\right) \delta: 7.54-7.64(5 \mathrm{H}, \mathrm{m}), 7.72(1 \mathrm{H}, \mathrm{d}, J=7.5 \mathrm{~Hz}), 7.80(1 \mathrm{H}, \mathrm{s})$, $7.87(1 \mathrm{H}, \mathrm{d}, J=7.8 \mathrm{~Hz}), 8.20(1 \mathrm{H}, \mathrm{s}), 8.52(1 \mathrm{H}, \mathrm{s}), 8.67(1 \mathrm{H}$, s). IR (KBr) $\mathrm{cm}^{-1}: 3394,3070,1605$. GC-MS (ESI) $\mathrm{m} / \mathrm{z}: 384$ $\left(\mathrm{M}+2 \neg^{+\cdot}\right), 382\left(\mathrm{M} \neg^{+\cdot}\right), 381\left(\mathrm{M}-1 \neg^{+}\right)$. Anal. Calcd for $\mathrm{C}_{18} \mathrm{H}_{11} \mathrm{ClN}_{4} \mathrm{O}_{2} \mathrm{~S}: \mathrm{C}, 56.47 ; \mathrm{H}, 2.90 ; \mathrm{N}, 14.64$. Found: C, 56.19; $\mathrm{H}, 2.98 ; \mathrm{N}, 14.60$.

[5-(4-Chlorophenyl)thieno[2,3-d]pyrimidin-4-yl]-(3,4dichloro-phenyl)amine (4h)

Yield, 69\% (acetone). mp $164-166^{\circ} \mathrm{C} .{ }^{1} \mathrm{H}-\mathrm{NMR}$ (DMSO- $d_{6}$ ) $\delta: 7.23(1 \mathrm{H}, \mathrm{d}, J=2.4 \mathrm{~Hz}), 7.26(1 \mathrm{H}, \mathrm{d}, J=2.4 \mathrm{~Hz}), 7.52-7.61$ $(4 \mathrm{H}, \mathrm{m}), 7.77(1 \mathrm{H}, \mathrm{s}), 7.91(1 \mathrm{H}, \mathrm{s}), 7.92(1 \mathrm{H}, \mathrm{s}), 8.63(1 \mathrm{H}, \mathrm{s}) . \mathrm{IR}$ (KBr) $\mathrm{cm}^{-1}:$ 3402, 3040, 1600. Anal. Calcd for $\mathrm{C}_{18} \mathrm{H}_{10} \mathrm{Cl}_{3} \mathrm{~N}_{3} \mathrm{~S}$ : C, 53.16; H, 2.48; N, 10.33. Found: C, 53.28; H, 2.54; N, 10.52.

(4-Bromophenyl)-[5-(4-chloro-phenyl)thieno[2,3-d]pyrimidin-4-yl]amine (4i)

Yield, 80\% (acetone). mp $160-162^{\circ} \mathrm{C} .{ }^{1} \mathrm{H}-\mathrm{NMR}$ (DMSO$\left.d_{6}\right) \delta: 7.39(2 \mathrm{H}, \mathrm{d}, J=8.2 \mathrm{~Hz}), 7.47(2 \mathrm{H}, \mathrm{d}, J=9 \mathrm{~Hz}), 7.59-7.65$ $(4 \mathrm{H}, \mathrm{m}), 7.65(1 \mathrm{H}, \mathrm{s}), 7.74(1 \mathrm{H}, \mathrm{s}), 8.59(1 \mathrm{H}, \mathrm{s}) . \mathrm{IR}(\mathrm{KBr}) \mathrm{cm}^{-1}$ : 3406, 3050, 1600. GC-MS (ESI) $m / z: 418\left(\mathrm{M}+2 \neg^{+*}\right), 416$ $\left(\mathrm{M} \neg^{+\cdot}\right)$. Anal. Calcd for $\mathrm{C}_{18} \mathrm{H}_{11} \mathrm{BrClN}_{3} \mathrm{~S}: \mathrm{C}, 51.88 ; \mathrm{H}, 2.66 ; \mathrm{N}$, 10.08. Found: C, 51.91; H, 2.63; N, 10.21.

[5-(4-Nitrophenyl)thieno[2,3-d]pyrimidin-4-yl]m-tolylamine (4j)

Yield, 68\% (acetone). mp $130-132^{\circ} \mathrm{C} .{ }^{1} \mathrm{H}-\mathrm{NMR}$ (DMSO$\left.d_{6}\right) \delta: 2.24(3 \mathrm{H}, \mathrm{s}), 6.85(1 \mathrm{H}, \mathrm{t}, J=5.4,5.4 \mathrm{~Hz}), 7.14(2 \mathrm{H}, \mathrm{d}$, $J=4.8 \mathrm{~Hz}), 7.23(1 \mathrm{H}, \mathrm{s}), 7.80(2 \mathrm{H}, \mathrm{d}, J=8.7 \mathrm{~Hz}), 7.84(1 \mathrm{H}, \mathrm{s})$, $7.89(1 \mathrm{H}, \mathrm{s}), 8.31(2 \mathrm{H}, \mathrm{d}, J=8.7 \mathrm{~Hz}), 8.57(1 \mathrm{H}, \mathrm{s})$. IR $(\mathrm{KBr})$ $\mathrm{cm}^{-1}$ : 3398, 3050, 1608, 2920. Anal. Calcd for $\mathrm{C}_{19} \mathrm{H}_{14} \mathrm{~N}_{4} \mathrm{O}_{2} \mathrm{~S}$ : C, 62.79; H, 3.89; N, 15.46. Found: C, 63.08; H3.91; N, 15.63. (4k)

[5-(4-Nitrophenyl)thieno[2,3- $d]$ pyrimidin-4-yl] $p$-tolylamine

Yield, 70\% (acetone). mp 210-212 ${ }^{\circ} \mathrm{C} .{ }^{1} \mathrm{H}-\mathrm{NMR}$ (DMSO- $d_{6}$ ) $\delta: 2.25(3 \mathrm{H}, \mathrm{s}), 7.08(2 \mathrm{H}, \mathrm{d}, J=8.7 \mathrm{~Hz}), 7.29(2 \mathrm{H}, \mathrm{d}, J=8.7 \mathrm{~Hz})$, $7.66(1 \mathrm{H}, \mathrm{s}), 7.82(2 \mathrm{H}, \mathrm{d}, J=8.7 \mathrm{~Hz}), 7.86(1 \mathrm{H}, \mathrm{s}), 8.32(2 \mathrm{H}$, d, $J=8.7 \mathrm{~Hz}), 8.54(1 \mathrm{H}, \mathrm{s})$. IR $(\mathrm{KBr}) \mathrm{cm}^{-1}: 3417,3043,1608$,
2930. Anal. Calcd for $\mathrm{C}_{19} \mathrm{H}_{14} \mathrm{~N}_{4} \mathrm{O}_{2} \mathrm{~S}: \mathrm{C}, 62.79 ; \mathrm{H}, 3.89 ; \mathrm{N}$, 15.46. Found: C, 63.03; H, 3.91; N, 15.62.

4-[5-(4-Nitrophenyl)thieno[2,3-d]pyrimidin-4-ylamino]phenol (4I)

Yield, 64\% (ethanol). mp 270-272 ${ }^{\circ} \mathrm{C} .{ }^{1} \mathrm{H}-\mathrm{NMR}$ (DMSO- $d_{6}$ ) $\delta: 6.67(2 \mathrm{H}, \mathrm{d}, J=8.7 \mathrm{~Hz}), 7.16(2 \mathrm{H}, \mathrm{d}, J=8.7 \mathrm{~Hz}), 7.51(1 \mathrm{H}, \mathrm{s})$, $7.82-7.85(3 \mathrm{H}, \mathrm{m}), 8.33(2 \mathrm{H}, \mathrm{d}, J=8.7 \mathrm{~Hz}), 8.46(1 \mathrm{H}, \mathrm{s}), 9.30$ $(1 \mathrm{H}, \mathrm{s}) .{ }^{13} \mathrm{C}-\mathrm{NMR}$ (DMSO- $\left.d_{6}\right) \delta: 167.6,157.1,148.4,147.4$, $142.7,142.3,139.3,128.2,127.9,124.4,124.2,121.8,116.5$. IR (KBr) $\mathrm{cm}^{-1}:$ 3444, 3402, 3066, 1604. GC-MS (ESI) m/z 365(M+1 $\left.\neg^{+\cdot}\right)$. Anal. Calcd for $\mathrm{C}_{18} \mathrm{H}_{12} \mathrm{~N}_{4} \mathrm{O}_{3} \mathrm{~S}$ : C, 59.33; H, 3.32; N, 15.38. Found: C, 59.32; H, 3.34; N, 15.44.

(4-Chlorophenyl)-[5-(4-nitrophenyl)thieno[2,3-d]pyrimidin-4-yl]amine (4m)

Yield, 73\% (acetone). mp $210-212{ }^{\circ} \mathrm{C} .{ }^{1} \mathrm{H}-\mathrm{NMR}$ (DMSO- $d_{6}$ ) $\delta$ : $7.32(2 \mathrm{H}, \mathrm{d}, J=8.7 \mathrm{~Hz}), 7.46(2 \mathrm{H}, \mathrm{dd}, J=8.7,8.7 \mathrm{~Hz}), 7.82$ $(2 \mathrm{H}, \mathrm{dd}, J=8.7,8.7 \mathrm{~Hz}), 7.93(1 \mathrm{H}, \mathrm{s}), 8.02(1 \mathrm{H}, \mathrm{s}), 8.31(2 \mathrm{H}$, d, $J=8.7 \mathrm{~Hz}), 8.60(1 \mathrm{H}, \mathrm{s}) . \mathrm{IR}(\mathrm{KBr}) \mathrm{cm}^{-1}: 3425,3105,3062$, 1604. GC-MS (ESI) $m / z$ : $384\left(\mathrm{M}+2 \neg^{+\cdot}\right), 382\left(\mathrm{M} \neg^{+\cdot}\right), 381$ $\left(\mathrm{M}-1 \neg^{+}\right)$. Anal. Calcd for $\mathrm{C}_{18} \mathrm{H}_{11} \mathrm{ClN}_{4} \mathrm{O}_{2} \mathrm{~S}: \mathrm{C}, 56.47 ; \mathrm{H}, 2.90$; N, 14.64. Found: C, 56.51; H, 2.93; N, 14.81 .

2-[5-(4-Nitrophenyl)thieno[2,3- $d$ ]pyrimidin-4-ylamino]benzoic Acid (4n)

Yield, 55\% (isopropanol). $\mathrm{mp} \quad 300-302^{\circ} \mathrm{C} . \quad{ }^{1} \mathrm{H}-\mathrm{NMR}$ $\left(\mathrm{DMSO}_{6}\right) \delta: 7.77-7.83(5 \mathrm{H}, \mathrm{m}), 8.16(1 \mathrm{H}, \mathrm{s}), 8.19-8.26(4 \mathrm{H}$, m), 12.60 (2H, s). IR (KBr) cm $\mathrm{cm}^{-1}$ 3356, 3290, 3101, 3059, 1732, 1643. GC-MS (ESI) m/z: $393\left(\mathrm{M}+1 \neg^{+\cdot}\right)$. Anal. Calcd for $\mathrm{C}_{19} \mathrm{H}_{12} \mathrm{~N}_{4} \mathrm{O}_{4} \mathrm{~S}: \mathrm{C}, 58.16 ; \mathrm{H}, 3.08 ; \mathrm{N}, 14.28$. Found: C, 58.28; H, $3.11 ; \mathrm{N}, 14.43$.

4-[5-(4-Nitrophenyl)thieno[2,3-d]pyrimidin-4-ylamino]benzoic Acid (4o)

Yield, 69\% (acetic acid). mp $240-242{ }^{\circ} \mathrm{C} .{ }^{1} \mathrm{H}-\mathrm{NMR}$ (DMSO$\left.d_{6}\right) \delta: 6.52(1 \mathrm{H}, \mathrm{d}, J=6.3 \mathrm{~Hz}), 7.55-7.86(4 \mathrm{H}, \mathrm{m}), 7.98(1 \mathrm{H}, \mathrm{s})$, 7.82-8.32 (4H, m), $8.69(1 \mathrm{H}, \mathrm{s}), 12.63(1 \mathrm{H}, \mathrm{s})$. GC-MS (ESI) $\mathrm{m} / \mathrm{z} 392\left(\mathrm{M} \neg^{+}\right)$. IR (KBr) $\mathrm{cm}^{-1}:$ 3414, 3055, 1705, 1608. Anal. Calcd for $\mathrm{C}_{19} \mathrm{H}_{12} \mathrm{~N}_{4} \mathrm{O}_{4} \mathrm{~S}$ : C, 58.16; H, 3.08; N, 14.28. Found: C, 58.38; H, 3.10; N, 14.50.

(3-Nitrophenyl)-[5-(4-nitro-phenyl)thieno[2,3-d]pyrimidin-4-yl]amine (4p)

Yield, 63\% (acetone). mp 220-222 ${ }^{\circ} \mathrm{C} .{ }^{1} \mathrm{H}-\mathrm{NMR}$ (DMSO- $d_{6}$ ) $\delta: 7.54(1 \mathrm{H}, \mathrm{t}, J=7.8,7.8 \mathrm{~Hz}), 7.74(1 \mathrm{H}, \mathrm{d}, J=9 \mathrm{~Hz}), 7.80-7.85$ $(3 \mathrm{H}, \mathrm{m}), 7.99(1 \mathrm{H}, \mathrm{s}), 8.22-8.32(2 \mathrm{H}, \mathrm{m}), 8.40(1 \mathrm{H}, \mathrm{s}), 8.49$ $(1 \mathrm{H}, \mathrm{s}), 8.68(1 \mathrm{H}, \mathrm{s})$. IR $(\mathrm{KBr}) \mathrm{cm}^{-1}: 3421,3078,1601$. Anal. Calcd for $\mathrm{C}_{18} \mathrm{H}_{11} \mathrm{~N}_{5} \mathrm{O}_{4} \mathrm{~S}: \mathrm{C}, 54.96 ; \mathrm{H}, 2.82 ; \mathrm{N}, 17.80$. Found: $\mathrm{C}$, 55.05; H, 2.80; N, 17.93 .

(4-Bromophenyl)-[5-(4-nitrophenyl)thieno[2,3-d]pyrimidin-4-yl] amine (4q)

Yield, 70\% (ethanol). mp 206-208 ${ }^{\circ} \mathrm{C}$. ${ }^{1} \mathrm{H}-\mathrm{NMR}$ (DMSO$\left.d_{6}\right) \delta: 7.40-7.47(3 \mathrm{H}, \mathrm{m}), 7.48(1 \mathrm{H}, \mathrm{s}), 7.82-7.85(3 \mathrm{H}, \mathrm{m}), 7.91$ $(1 \mathrm{H}, \mathrm{s}, \mathrm{NH}), 8.30(2 \mathrm{H}, \mathrm{d}, J=8.7 \mathrm{~Hz}), 8.60(1 \mathrm{H}, \mathrm{s}) .{ }^{13} \mathrm{C}-\mathrm{NMR}$ $\left(\mathrm{DMSO}-d_{6}\right) \delta: 167.6,157.1,148.4,145.8,142.6,142.3,132.6$, 128.2, 127.9, 124.4, 124.2, 121.8, 117.4, 113.1. IR (KBr) cm $\mathrm{cm}^{-1}$ : 3417, 3383, 3097, 3059, 1608. GC-MS (ESI) $\mathrm{m} / \mathrm{z}: 429,427$ $\left(\mathrm{M} \neg{ }^{+\cdot}\right)$, 425. Anal. Calcd for $\mathrm{C}_{18} \mathrm{H}_{11} \mathrm{BrN}_{4} \mathrm{O}_{2} \mathrm{~S}: \mathrm{C}, 50.60 ; \mathrm{H}$, 2.59; N, 13.11. Found: C, 50.61; H, 2.60; N, 13.01.

Docking Studies The X-ray crystallographic structure of EGFR complexed with Lapatinib (PDB ID: 1XKK) was obtained from protein data bank available at the RCSB Protein Data Bank, http://www.rcsb.org.

Compounds were built using Molecular Operating Environment (MOE) molecule builder. The structures were energy 
minimized. Compounds were docked using the MOE dock tool. Poses generated by the placement methodology were scored and then subjected to MMFF94x energy minimization. For each docked compound only one pose was selected based on number of binding interactions, superposition with the original ligand, docking score and the formed H-bonds lengths (Table 1).

Cytotoxic Activity The antitumor activity was determined for the newly synthesized compounds in Egyptian National Cancer Institute (NCI) for in-vitro detection of $\mathrm{IC}_{50}$ of their antitumor activity and was repeated three times $(n=3)$. The breast tumor cell line (MCF-7) was obtained frozen in liquid nitrogen $\left(-180^{\circ} \mathrm{C}\right)$ from the American Type Culture Collection (ATCC) and was maintained in the National Cancer Institute, Cairo, Egypt, by serial sub-culturing. All chemicals used in this study are of high analytical grade. They were obtained from (either Sigma-Aldrich or Bio-Rad). The cytotoxicity of the test compounds was determined using SRB assay applying the method of Monk et al. ${ }^{30)}$ The Cells were plated in 96-multiwell plate $\left(10^{4}\right.$ cells/well $)$ for $24 \mathrm{~h}$ before treatment with the compounds to allow the attachment of cells to the wall of the plate. Different concentrations of each compound $(0,1,2.5,5,10 \mu \mathrm{g} / \mathrm{mL})$ were added to the cell monolayer triplicate wells were prepared for each individual dose. Monolayer cells were incubated with the compounds for $48 \mathrm{~h}$ at $37^{\circ} \mathrm{C}$ and in atmosphere of $5 \% \mathrm{CO}_{2}$. After $48 \mathrm{~h}$, cells were fixed, washed, and stained with sulforhodamine $\mathrm{B}$ stain. Excess stain was washed with acetic acid and attached stain was recovered with tris ethylenediaminetetraacetic acid (EDTA) buffer. Color intensity was measured in an ELISA reader. The relation between surviving fraction and drug concentration was plotted to get the survival curve of each tumor cell line. The $\mathrm{IC}_{50}$ value was calculated using sigmoidal dose response curve-fitting models (Graph Pad, Prizm Software Incorporated), each concentration was repeated 3 times.

Protein Tyrosine Kinase Inhibition Assay This assay was performed according to Rijksen et al. method $^{31)}$ using SIGMA Protein Tyrosine Kinase Assay Kit and ROBONIK P2000 spectrophotometer wl $450 \mathrm{~nm}$ reader. The assay was carried out three times for every $\mathrm{IC}_{50}$ dose of each target compound.

Acknowledgments The authors are grateful to all members of the Cancer Biology Department, National Cancer Institute, Cairo, Egypt, for carrying out the cytotoxicity testing. The authors are grateful to all members of confirmatory diagnostic unit, VACSERA-Egypt.

Conflict of Interest The authors declare no conflict of interest.

\section{References}

1) Siegel R., Ma J., Zou Z., Jemal A., CA Cancer J. Clin., 64, 9-29 (2014).

2) Globocan, International Agency for Research on Cancer (2013), http://globocan.iarc.fr.

3) Khan I., Ibrar A., Abbas N., Saeed A., Eur. J. Med. Chem., 76, 193-244 (2014).

4) Dar A. C., Shokat K. M., Annu. Rev. Biochem., 80, 769-795 (2011). 5) Zhang J., Yang P. L., Gray N. S., Nat. Rev. Cancer, 9, 28-39 (2009).

6) Ciardiello F., Tortora G., Clin. Cancer Res., 7, 2958-2970 (2001).
7) Rusnak D. W., Lackey K., Affleck K., Wood E. R., Alligood K. J., Rhodes N., Keith B. R., Murray D. M., Knight W. B., Mullin R. J., Gilmer T. M., Mol. Cancer Ther., 1, 85-94 (2001).

8) Wakeling A. E., Barker A. J., Davies D. H., Brown D. S., Green L. R., Cartlidge S. A., Woodburn J. R., Breast Cancer Res. Treat., 38, 67-73 (1996)

9) Liao J. J., J. Med. Chem., 50, 409-424 (2007).

10) Ashalatha B. V., Narayana B., Raj K. K. V., Kumari N. S. S., Eur. J. Med. Chem., 42, 719-728 (2007).

11) Liu Y., Gray N. S., Nat. Chem. Biol., 2, 358-364 (2006).

12) Pierce A. C., Sandretto K. L., Bemis G. W., Proteins, 49, 567-576 (2002)

13) Wood E. R., Truesdale A. T., McDonald O. B., Yuan D., Hassell A., Dickerson S. H., Ellis B., Pennisi C., Horne E., Lackey K., Alligood K. J., Rusnak D. W., Gilmer T. M., Shewchuk L., Cancer Res., 64, 6652-6659 (2004).

14) Goldstein N. I., Prewett M., Zuklys K., Rockwell P., Mendelsohn J., Clin. Cancer Res., 1, 1311-1318 (1995).

15) Chen G., Luo X., Zhu W., Luo C., Liu H., Puah C. M., Chen K., Jiang H., Bioorg. Med. Chem., 12, 2409-2417 (2004).

16) Vema A., Panigrahi S. K., Rambabu G., Gopalakrishnan B., Sarma J. A., Desiraju G. R., Bioorg. Med. Chem., 11, 4643-4653 (2003).

17) Bohm H. J., Flohr A., Stah M., Technology, 1, 217-224 (2004).

18) Carreras C. W., Santi D. V., Annu. Rev. Biochem., 64, 721-762 (1995).

19) Gangjee L., Qiu Y., Kisliuk R. L., J. Heterocycl. Chem., 41, 941946 (2004).

20) Ubersax J. A., Woodbury E. L., Quang P. N., Paraz M., Blethrow J. D., Shah K., Shokat K. M., Morgan D. O., Nature (London), 425, 859-864 (2003).

21) Horiuchi T., Nagata M., Kitagawa M., Akahane K., Uoto K., Bioorg. Med. Chem., 17, 7850-7860 (2009).

22) Guo Z., Chen Y., Wu D., Zhu Y. F., Struthers R. S., Saunders J., Xie Q., Chen C., Bioorg. Med. Chem. Lett., 13, 3617-3622 (2003).

23) Munchhof M. J., Beebe J. S., Casavant J. M., Cooper B. A., Doty J. L., Higdon R. C., Hillerman S. M., Soderstrom C. I., Knauth E. A., Marx M. A., Rossi A. M. K., Sobolov S. B., Sun J., Bioorg. Med. Chem. Lett., 14, 21-24 (2004).

24) Dai Y., Guo Y., Frey R. R., Ji Z., Curtin M. L., Ahmed A. A., Albert D. H., Arnold L., Arries S. S., Barlozzari T., Bauch J. L., Bouska J. J., Bousquet P. F., Cunha G. A., Glaser K. B., Guo J., Li J., Marcotte P. A., Marsh K. C., Moskey M. D., Pease L. J., Stewart K. D., Stoll V. S., Tapang P., Wishart N., Davidsen S. K., Michaelides M. R., J. Med. Chem., 48, 6066-6083 (2005).

25) Rheault T. R., Caferro T. R., Dickerson S. H., Donaldson K. H., Gaul M. D., Goetz A. S., Mullin R. J., McDonald O. B., Petrov K. G., Rusnak D. W., Shewchuk L. M., Spehar G. M., Truesdale A. T., Vanderwall D. E., Wood E. R., Uehling D. E., Fuel J. Pharm. Sci., 19, 817-820 (2009).

26) Pedeboscq S., Gravier D., Casadebaig F., Hou G., Gissot A., De Giorgi F., Ichas F., Cambar J., Pometan J. P., Eur. J. Med. Chem., 45, 2473-2479 (2010).

27) Zhao A., Gao X., Wang Y., Ai J., Wang Y., Chen Y., Geng M., Zhang A., Bioorg. Med. Chem., 19, 3906-3918 (2011).

28) Gryshchenko A. A., Bdzhola V. G., Balanda A. O., Briukhovetska N. V., Kotey I. M., Golub A. G., Ruban T. P., Lukash L. L., Yarmoluk S. M., Bioorg. Med. Chem., 23, 2287-2293 (2015).

29) El-Ansary A. K., Kamal A. M., Al-Ghorafi M. A.-H., Eur. J. Med. Chem., 86, 202-210 (2014).

30) Monks A., Scudiero D., Skehan P., Shoemaker R., Paull K., Vistica D., Hose C., Langley J., Cronise P., Vaigro-wolff A., Gray-Goodrich M., Campbell H., Mayo J., Boyd M., J. Natl. Cancer Inst., 83, 757-766 (1991).

31) Rijksen G., Van Oirschot B. A., Staal G. E. J., Methods Enzymol., 200, 98-107 (1991). 